\title{
İlköğretim Öğrencilerine Rol Oynama (Rol-Play) Yöntemi ile Uygulanan El Hijyeni Eğitiminin Öğrencilerin EI Yıkama Bilgi ve Becerilerine Etkisi
}

\author{
Hatice YUMRU ${ }^{1}$ (D) Şerife KOÇ
}

${ }^{1}$ Öğr. Gör., Karamanoğlu Mehmetbey Üniversitesi, Sağlık Hizmetleri Meslek Yüksekokulu, Tıbbi Hizmetler ve Teknikler Bölümü, Karaman, Türkiye ${ }^{2}$ Dr. Öğr. Üyesi, Karamanoğlu Mehmetbey Üniversitesi, Sağlık Bilimleri Fakültesi, Halk Sağlığı Hemşireliği Anabilim Dalı, Karaman, Türkiye

\section{Öz}

Giriş: Doğru el hijyeni alışkanlığı, enfeksiyon hastalıklarının önlenmesinde, okul ortamında yayılımını engellemede, enfeksiyon hastalıklarına bağlı tedavi maliyetlerini ve okul devamsızlığını azaltmada öğrencilere kazandırılması gereken en temel bilgi ve beceridir. Küçük yaşlarda öğrenilen kişisel hijyen uygulamalarının kalıcı bir davranış haline gelmesinin daha kolaydır. Bu nedenle ilköğretim çağında verilen hijyen eğitimleri çok önemlidir. Bireyin, ailenin ve toplumun sağlığını korumak, geliştirmek ve doğru sağlık davranışları kazandırmak amacıyla planlı sağlık eğitimleri yapmak, hemşirelerin en önemli rolleri ve temel görevleri arasındadır. Amaç: Bu çalışma ilköğretim öğrencilerine Rol Oynama (Rol-Play) yöntemi ile uygulanan el hijyeni eğitiminin öğrencilerin el yıkama bilgi ve becerilerine etkisini değerlendirmek amacıyla yapılmıştır. Yöntem: Araştırma tek grup ön test-son test tasarımda Mayıs 2019-Haziran 2019 tarihlerinde, Karaman ilindeki bir ilköğretim okulunda 3. ve 4. sınıfta öğrenim gören 194 öğrenci ile yapıldı. Veriler Sosyo-Demografik Özellikler Formu ve Doğru El Yıkama Değerlendirme Formu ile toplandı. Çalışma sonunda elde edilen veriler Statistical Package for the Social Sciences (SPSS)-21.00 programı kullanılarak kaydedilmiş ve veriler normal dağılıma uyup uymadığına göre uygun tanımlayıcı (sıklık, yüzde, vb.), ilişki arayıcı (McNemar) istatistik analizlerle değerlendirilmiştir. Bulgular: Öğrenciler ellerini en fazla kirlendiği zaman (\%94.3) yıkadıklarını bildirmişlerdir. Öğrencilerin eğitim öncesi ve sonrası el hijyeni bilgi ve becerileri karşılaştırıldığında, el yıkama eğitimi sonrası öğrencilerin el yıkamaya ilişkin bilgi ve becerilerinde eğitim öncesine göre istatistiksel olarak anlamlı fark saptanmıştır ( $<<.001)$. Sonuç: Rol Oynama (Rol-Play) yöntemi kullanılarak yapılan el hijyeni eğitimi sonrasında çocukların bilgi ve becerilerinde olumlu yönde artış saptanmıştır. Bu çalışmada kullanılan rol-play yöntemi çocuklara eğlenerek öğretmeyi sağlamış ve destekleyici bir eğitim yöntemi olarak kullanılmıştır.

Anahtar Sözcükler: Çocuk Sağlığı, El Hijyeni, Sağlık Eğitimi, Rol-Play, Okul Sağlığı Hemşireliğii.

Abstract
Effect of Hand Hygiene Education Implemented through the Role-Play Method on Knowledge and Behavior of
Primary School Students
Background: In order to decrease the cost of treating infectious diseases and kid's absenteeism in school, the most core knowledge and skill
that should be taught to students in avoiding infectious diseases in the school environmentis the accurate hand hygiene. Personal hygiene
practices learned at an early age are easier to become permanent behavior. Hygiene training given in primary school age is very important in
this business. Teaching kids' hand hygiene is efficient for a healthy society. Health education is one of the important roles of nurses.
Objectives: This study aims to evaluate the effects of hand hygiene education applied through Role-Play Method on hand washing knowledge
and skills of primary school students. Methods: The study was conducted between May 2019-June 2019 on $1943^{\text {rd }}$ and $4^{\text {th }}$ graders in a primary
school in Karaman. The data were collected through socio-demographic attributes form and correct hand washing rating form. The obtained
data were evaluated with descriptive statistics and McNemar tests. Results: Students reported that they wash their hands when they are dirtiest
(94.3\%). Comparing the students' knowledge and skill of hand hygiene before and after the education, a statistically significant difference was
determined after the hand washing education (p<.001). Conclusion: A positive increase was determined in the knowledge and skills of kids
after hand hygiene education using Role-Play Method. Role-Play method made learning fun for kids as a promotive education method.
Key Words: Child Health, Hand Hygiene, Health Education, Role-Play, School Health Nursing.

Geliş Tarihi / Received: 13.06.2020 Kabul Tarihi / Accepted: 23.04.2021

Araştırma 20 Aralık 2019 tarihinde Ankara' da düzenlenen 6. Uluslararası 17. Ulusal Hemşirelik Kongresinde sözel bildiri olarak sunulmuştur.

Correspondence Author: Öğr. Gör., Karamanoğlu Mehmetbey Üniversitesi, Sağlık Hizmetleri Meslek Yüksekokulu, Tıbbi Hizmetler ve Teknikler Bölümü, Karaman, Türkiye Telefon: +90 3382262754 E-posta: haticeyumru@kmu.edu.tr

Cite This Article: Yumru H, Koç Ş. İlköğretim Öğrencilerine Rol Oynama (Rol-Play) Yöntemi ile Uygulanan El Hijyeni Eğitiminin Öğrencilerin El Yıkama Bilgi ve Becerilerine Etkisi. Dokuz Eylül Üniversitesi Hemşirelik Fakültesi Elektronik Dergisi. 2021; 14(3): 188- 198 
$\mathbf{O}$ kul, eğitim öğretim kurumu olmanın yanında çocukların zamanının çoğunu geçirdiği, toplumsal yaşamla ilgili bilgi ve becerileri edindiği, sağlıkla ilgili temel bilgi ve alışkanlıkları öğrendiği, her bakımdan sosyalleştiği bir kurumdur. Okulların toplu yaşam yeri olduğu düşünüldüğünde hijyen sorunları nedeniyle okullarda enfeksiyonların gelişme ve bulaşma riski fazladır (1-3). Türkiye'de 7-14 yaş okul çağı çocuklarda enfeksiyöz hastalıklar 2010 yılında \%14,2; 2014 yılında $\% 9,4$; ve 2016 yılında \% 7,9 görülme sıklığı ile en sık görülen hastalıklar arasında ilk üç sıradadır $(4,5) .2019$ yılı verilerine göre enfeksiyöz hastalıkları çocuklarda son 6 ay içinde görülen sağlık sorunları arasında birinci sırada yer almaktadır (6).

Enfeksiyon hastalıkları yetersiz ya da yanlıs hijyen uygulamaları nedeniyle yayılmaktadır. Özellikle ilkokul çağı çocuklarının temel kişisel hijyen bilgilerinde ve becerilerinde yetersizlikler olması, sınıf, tuvalet ve lavaboların ortak kullanım alanı olması, çocukların okul ortamında her şeye dokunmaları, sürekli temas ve iletişim halinde olmaları, ellerini ağza götürme davranışları, farklı aile yapısına sahip olan çocukların aileden aldıkları eğitim ve farklı hijyen uygulamaları nedeniyle okul çağı çocuklar enfeksiyon hastalıkları açısından risk altındadır (1,7-9).

El hijyeni; enfeksiyon hastalıklarından korunmada ve kontrol altına almada en basit, en etkili ve en ucuz birincil koruma uygulamalarındandır. Ayrıca biyolojik, fiziksel ve kimyasal maddelerin vücuttan uzaklaştırılmasını amaçlayan kişisel hijyen uygulamalarından biridir (1-3,8-12). El hijyeni uygulamaları ile bulaşıcı hastalıklar, okul devamsızlığı, solunum sistemi ve gastrointestinal sistem hastalıkları insidansında azalma sağlandığı bilinmektedir $(2,3,9,13)$.

Sağlıklı toplumların oluşturulması çocuklara sağlık bilgilerinin doğru anlatılması ve doğru sağlık davranışlarının kazandırılması ile mümkündür. Aileden edinilen hijyen bilgilerini, okulda öğrendikleri ile pekiş̧iren çocuklar sağlıklı birey olma yolunda ilerleyecektir. Ergenlik ya da yetişkinlik dönemine kadar oluşan yanlış inanç ve alışkanlıkların değiştirilmesinin güçtür. $\mathrm{Bu}$ nedenle, küçük yaşlarda öğrenilen kişisel hijyen uygulamalarının kalıcı bir davranış haline gelmesinin daha kolay olacağı düşünüldüğünde ilköğretim çağında verilen hijyen eğitimleri çok önemlidir. El yıkama işlemi basit ve uygulanabilir olmasına ve el yıkamanın öneminin kişiler tarafından bilinmesine rağmen doğru el yıkama davranışının yeterli düzeyde olmadığı belirtilmektedir $(2,7,8,14,15)$. Bu durum hijyen eğitiminin daha farklı ve etkili yöntemlerle yapılması gerektiğini göstermektedir.

Bireyin, ailenin ve toplumun sağlı̆̆ını korumak, geliştirmek ve doğru sağlık davranışları kazanmasını sağlamak amacıyla planlı biçimde eğitim vermek, toplumda sağlıklı /hasta bireylerle en çok iletişim halinde olan hemşirelerin temel görevleri arasında yer almaktadır (3,14,16-20). Amerika Ulusal Okul Hemşireleri Birliği (National Association of School Nurses-NASN) tarafindan yayınlanan "Okul Hemşireleri Uygulamaları; Rolleri ve Standartları"nda sağlık eğitimi okul hemşireliği rol ve standartları arasında belirtilmiştir (21). Ayrıca Amerikan Hemşireler Birliği (American Nurses AssociationANA) ve Amerika Ulusal Okul Hemşireleri Birliği (National Association of School Nurses-NASN) tarafindan güncellenen "Okul Hemşireliğinin Kapsamı ve Uygulama Standartları" nda sağlık eğitimi ve danışmanlık okul hemşireliği uygulama standartları ve profesyonel performans standartları arasında yer almaktadır (22). Sağlık Bakanlığı tarafindan yayınlanan "Hemşirelik Yönetmeliğinde Değişiklik Yapılmasına Dair Yönetmelik”te tanımlanan okul sağlı̆̆ hemşiresinin görev, yetki ve sorumluluklarından biri de okul toplumuna ve öğrencilere doğru sağlık bilgisini aktarma ve olumlu sağlık davranışlarının kazandırılması amacıyla sağlık eğitimi faaliyetleri planlama ve yürütme olarak belirlenmiştir (23). Çocukların sağlığını koruma ve geliştirmenin yanı sıra okulda enfeksiyon hastalıklarını önlemek, bu hastalıkların yayılımını, hastaneye yatışı, tedavi maliyetlerini ve okul devamsızlığını azaltmak için el hijyeninin uygun yöntemlerle en doğru bir şekilde öğretilmesinde okul sağlı̆̆ hemşirelerine önemli görevler düşmektedir $(1,3,9,14,18,24)$.

El yıkama eğitiminde video/sunu destekli uygulanan çalışmalar bulunmakta olup $(1,3,7,8,11,17,18)$ bu çalışmalarda çocuklarda doğru el yıkama bilgi ve becerisi sağlamada etkin olduğu belirtilmiştir. İlkokul öğrencilerinde yapılan bir çalışmada kullanılan pedagojik yaklaşım ve akran eğitimi yönteminin el yıkama bilgi ve becerisini artırmada etkin sonuçlar sağlamıştır (25). Öncü ve arkadaşlarının (2018), yapmış olduğu çalışmada floresan jel uygulaması ile el yıkama işlemi sonrasında öğrencilerin ellerinin fotoğrafı çekilmiş ve ellerindeki floresan kalıntıları gösterilerek bu bölgelerin yeterince yıkanmadığı ve mikroplardan arınmadığı yönünde el hijyeni eğitimi verilmiş̧ir. Ancak çalışma sonucunda sadece floresan jel ile somutlaştırmanın yeterince etkili olmadığı, farklı motivasyon yöntemlerinin kullanılması gerektiği önerilmiştir (26). Cevizci ve arkadaşlarının (2014), yapmış olduğu çalışmada ise eğitim filmleri ve sunumlar kullanılarak verilen el hijyeni eğitimi sonucunda öğrencilerin el hijyeni bilgi ve uygulama düzeylerinin olumlu yönde değiştiği görülmüştür (1). Bu sonuçlara göre; okul çağındaki çocuklarda enfeksiyon hastalıklarına ilişkin çözüm önerileri belirlenmesi ve okullarda sağlığı geliştirme uygulamaları ile el yıkama becerisi geliştirilebileceği belirtilmiştir. Doğru el yıkama davranışı, gerekli bilgi ve becerilerin kazandırılması ile mümkündür. Doğru el yıkama, çocukların hayatı boyunca sergilemesi gereken bir davranış olduğundan okullarda farklı eğitim yöntemleri (posterler, simülasyonlar, senaryolar, videolar, rol oynama) kullanılarak yapılan eğitimlerle el yıkama becerileri kazandırılmalıdır $(9,19,13)$.

Çocukların ilgi ve isteğini artıracak, açı/net ve kolay eğitim materyalleri kullanılarak, çocukların da eğitimin içinde rol aldıkları interaktif uygulamalar ile doğru el yıkama eğitimlerinin verilmesi konusunda okul sağlığı hemşirelerine yönelik kanıta dayalı rehberler ve örnekler sunulmalıdır. Rol Oynama (Rol-Play), hemşirelikte farkındalığı artırmada kullanılan eğitim yöntemleri arasındadır. Rol play, eğitimde bilgi ve becerilerin öğretilmesinde sosyal iletişim becerileri, aktif dinleme, duyguların empati edilmesi ve gerçek yaşamdan kesitler görmeyi sağlayan beceri odaklı öğretim yöntemi olarak kullanılmaktadır (27-29). Özellikle çocukların oluşturduğu eğitim gruplarında, oyun teknikleri kullanılarak eğitimin etkinliği artırılabilir. Rol Oynama (Rol-Play) yöntemi çocuklara oynayarak öğrenme imkanı da sunacaktır. Çocukların sağlık davranışlarını geliştirmede bu yöntemin kullanılması çocuklara becerilerini test etme olanağı verecek ve öğrenmede kalıcıllğı sağlayacaktır (2). Rol-play, sağlık personeli-hasta iletişiminin öğretilmesi, hemşirelik öğrencilerine damar yolu açma işleminin öğretilmesi gibi tıp ve sağlık eğitimi alanında kullanıldığı çalışmalar bulunmaktadır $(30,31)$. Literatürde çocuklara verilen el hijyeni eğitiminde rol oynama eğitim yönteminin kullanıldığı sınırlı sayıda çalışma (28) vardır. El hijyeni eğitiminde Rol 
Oynama (Rol-Play) yönteminin el yıkama becerilerinin gelişmesinde katkı sağlayacağı ve etkin olacağı düşünülmektedir. Ayrıca literatüre farklı bir eğitim müdahale çalışması sunulmuş olacak hemşirelere ve öğretmenlere yol gösterecektir.

\section{Araştırmanın amact:}

İlköğretim öğrencilerine Rol Oynama (Rol-Play) yöntemi ile uygulanan el hijyeni eğitiminin öğrencilerin el yıkama bilgi ve becerilerine etkisini incelemektir.

\section{Araştırmanin hipotezleri:}

- Öğrencilerin el yıkama sıklığına, el yıkama bilgisine ve becerisine el yıkama eğitiminin etkisi yoktur.

- Öğrencilerin eğitim sonrasındaki el yıkama sıklığı eğitim öncesine göre daha fazla olacaktır.

- Öğrencilerin eğitim sonrasındaki el yıkama bilgi düzeyi eğitim öncesine göre daha yüksek olacaktır.

- Öğrencilerin eğitim sonrasındaki el yıkama becerisi eğitim öncesine göre artmıştır.

\section{Yöntem}

\section{Araştırmanın Tipi}

Araştırmada tek grup Öntest-Sontest yarı deneysel araştırma tasarımı kullanılmıştır.

\section{Araştırmanın Yapıldı̆̆ Yer}

Araştırma Karaman il merkezinde yer alan bir devlet ilkokulunda 2018-2019 eğitim öğretim döneminde 3. ve 4. sinıfta öğrenim gören öğrenciler ile 2019 yılı Mayıs-Haziran aylarında yürütülmüş̧ür.

\section{Araştırmanın Evreni/Örneklemi}

Araştırmanın evrenini Karaman il merkezinde bulunan bir ilkokulda öğrenim gören 3. ve 4. sınıf öğrencileri oluşturmaktadır. Okuma-yazma, veri toplama araçlarındaki soruları anlama ve yanıtlama zorluğu yaşayabileceğinden dolayı 1. ve 2. sınıf öğrencileri çalışmaya dâhil edilmemiş̧ir. 2018-2019 eğitim öğretim döneminde 3.sinıfta (118 öğrenci) ve 4. sinıfta (125 öğrenci) öğrenci kayıtlıdır $(\mathrm{N}=243)$. Araştırmada örneklem seçimine gidilmeyerek evrenin tamamına ulaşılmaya çalışılmıştır. Araştırmanın uygulanması için aile izni alınan, çalışmaya katılmada istekli olan, öntest ve sontest uygulamasının her ikisine katılan ve soruları eksiksiz yanıtlayan 194 öğrenci çalışmaya dâhil edilmiştir. Araştırmaya katılım oranı \%80 dir (194/243).

\section{Veri Toplama Araçları}

Araştırmada veri toplama araçları olarak literatür $(3,16,17)$ doğrultusunda oluşturulan Sosyo-Demografik Özellikler Formu ve Doğru El Yıkama Değerlendirme Formu (DEYDEF) kullanılmıştır.

Sosyo-demografik Özellikler Formu

Öğrencilerin yaş, sınıf, cinsiyet, anne ve babanın öğrenim durumu ve ellerini en son ne zaman yıkadıklarını içeren 9 soru yer almaktadır.

Doğru el yıkama değerlendirme formu (DEYDEF)

Öğrencilerin el yıkama bilgi, beceri ve durumlarını değerlendirmek amacıyla daha önce yapılan bir araştırmada (3) kullanılan, 2 bölümden oluşan bir formdur. Birinci bölümde öğrencilerin el yıkama sıklığını değerlendiren 8 önerme, el yıkamada önemli noktalara ilişkin bilgi durumunu değerlendiren 5 önerme olmak üzere 13 önerme bulunmaktadır. İkinci bölümde ise doğru el yıkama basamaklarını içeren ve öğrencilerin el yıkama becerilerini kontrol etmek için oluşturulan 14 maddelik kontrol listesi yer almaktadır. Formda el yıkama sıklı̆̆ ile ilgili önermeler "Evet" ve "Hayır" şeklinde yanıtlanmaktadır. El yıkamanın önemli noktalarına ilişkin önermeler "Evet" ve "Hayır" olarak değerlendirilmiştir. El yıkama "Elleri yıkamak için 10 saniye süre yeterlidir" ve "El temizliği için sadece su yeterlidir" ifadelerine verilen "Hayır" yanıtı doğru kabul edilmiş̧ir. Diğer önermelere ise "Evet" yanıtı doğru kabul edilmiştir. Doğru el yıkama becerileri ise, el yıkama basamaklarını değerlendiren gözlem formuna her bir basamak için "uygulandı" ya da "uygulanmadı" şeklinde işaretlenmiştir.

\section{Verilerin Toplanmast}

Araştırmanın verileri öğrencilerin eğitim gördüğ̈ ilkokulda öğrenciler ile yüz yüze görüşme ve gözlem yöntemi ile toplanmıştır. Veri toplamaya başlamadan önce kurum izni ve öğrencilerin velilerine Bilgilendirilmiş Olur Formu gönderilerek veli izni alınmıştır.

Veri toplama araçları öğrencilere eğitim öncesi ve eğitimden 1 ay sonra olmak üzere toplam iki kez uygulanmıştır. Veri toplama işlemi, formların doldurulması ( $5 \mathrm{dk}$.) ve el yıkama gözlemini $(2 \mathrm{dk}$.) içermektedir. Okul müdürü ve öğretmenler ile uygun ders saatleri ayarlanarak önce ön test uygulaması, sonra el yıkama gözlemi ve daha sonra el yıkama eğitimi yapılmıştır. Veri toplama araçları öğrencilere sınıfta dağıtılarak araştırmacı ve sınıf öğretmeni gözetiminde birbirleri ile etkileşmeleri önlenerek veri toplama formlarını doldurmaları sağlanmıştır. Daha sonra öğrenciler teker teker lavaboya alınarak eğitim öncesi el yıkama becerileri aynı araştırmacı tarafından gözlemlenmiştir. Uygulamalar sırasında tüm lavabolarda sabun ve kâğıt havlu bulundurulmuştur. El yıkama gözlemi sonrasında öğrencilere Rol Oynama (Rol-Play) Yöntemi ile El Hijyeni Eğitimi uygulanmıştır. Eğitim ikinci araştırmacı tarafından bir ders saati ( $40 \mathrm{dk}$.) olmak üzere her bir sınıfa ayrı verilmiş̧ir. Eğitimden 1 ay sonra bir ders saati ayarlanarak son test veri toplama işlemi yapılmıştır. Veri toplama araçlarının doldurulması yaklaşık 5 dakika (dk.), el yıkama gözlemi ise her öğrenci için ortalama $2 \mathrm{dk}$. sürmüştür.

El Yıkama Eğitimi:

El yıkama eğitimi, eğitime katılan öğrencilerin doğru el yıkama bilgi ve becerilerinde olumlu yönde değişikliğin olması amacıyla uygulanmıştır. Eğitiminin hedefi, öğrencilerin doğru el yıkama tekniklerini öğrenmesini ve uygulamasını sağlamaktır. Okul idaresi ile bir ders saati belirlenerek sınıf ortamında 35 dakikalık bir eğitim verilmiştir. Eğitime müdahale gününde okulda olan 203 öğrenci katılmış ancak aile izni olmayan 9 öğrenci araştırmaya dâhil edilmemiştir.

Eğitimin giriş bölümünde öğrencilere ( $5 \mathrm{dk}$.) eğitimin içeriği hakkında bilgi verilmiş ve soru-cevap teknikleri ile konuya dikkat çekilmiştir. Eğitimin gövde bölümünde bir senaryo eşliğinde tasarımı araştırmacı tarafından yapılan seyyar lavabo kullanılarak Rol Oynama (Rol-Play) yöntemi ile eğitim verilmiştir. Senaryo içeriğinde el hijyenine dikkat etmeyen, karın ağrısı şikayetiyle hastalanarak okul hemşiresine başvuran öğrencinin hemşire ile yaptığ görüşme canlandırılmıştır. Senaryoda okul hemşiresi mikrop kavramı, mikropların insan vücuduna bulaşma yolları ve bulaşmada ellerin rolü, ellerin hangi durumlarda 
yıkanması gerektiği gibi bilgileri içeren $10 \mathrm{dk}$. lık düz anlatım ile eğitim vererek hasta rolündeki öğrenciyi seyyar lavaboya yönlendirir ve birlikte el yıkama yapılır. Bu aşamada oyunculardan biri seyyar lavabonun arkasına geçerek lavaboyu konuşturur ve öğrenciye doğru el yıkama basamakları komutu verir. Aynı anda hemşire rolündeki araştırmacı tarafından doğru el yıkama basamakları takip edilerek demonstrasyon ile "örnek el yıkama" uygulaması yapılmıştır. Eğitim sonrasında öğrencilerin seyyar lavaboda uygulamayı tekrar etmeleri sağlanmış ve uygulama basamakları pekiş̧irilmiştir. Uygulama tekrarında öğrencilerin akranları ile etkileşimi de sağlanmıştır. Eğitimin sonuç bölümünde $5 \mathrm{dk}$. süre ile eğitim özetlenerek, soruları cevaplandırılmış, eğitimin değerlendirilmesi yapılmıştır. Planlı olarak hazırlanan senaryonun oynanmasında bir üniversitenin Hemşirelik bölümü son sınıf öğrencisi gönüllü 2 öğrenci ve ikinci araştırmacı görev almıştır.

\section{Araştırmanın Değiş̧kenleri}

Araştırmanın bağımlı değiş̧enleri öğrencilerin el yıkama sıklı̆̆ı, el yıkama bilgisi ve el yıkama davranışıdır. Bağımsız değişken ise Rol Oynama (Rol-Play) yöntemi ile uygulanan el hijyeni eğitimidir.

\section{Verilerin Değerlendirilmesi}

Araştırmadan elde edilen veriler Statistical Package for the Social Sciences (SPSS) 21.00 (IBM Corp. Armonk, NY: USA. Released 2012) programı kullanılarak değerlendirilmiştir. Veriler sayı, yüzde, McNemar analizleri ile değerlendirilmiştir. Tüm analizlerde $\mathrm{p}<0.05$ istatistiksel anlamlılık düzeyi olarak kabul edilmiştir.

\section{Araștırmanın Etik Yönü}

Araştırmanın uygulanması için bir üniversitenin Sağlık Bilimleri Fakültesine bağlı etik kurulundan etik izin (27.03.2019/18), çalışmanın yapıldığı ilin Valiliğinden ve İl Milli Eğitim Müdürlüğ̈̈’nden kurum izni (13.05.2019/99371540-44-E.9374641) alınmıştır.

Araştırmaya başlamadan önce ebeveynlerden yazılı izin, öğretmen ve öğrencilerden ise sözel izin alınmıştır. Çalışma için ebeveyni izin vermeyen/izin formu gelmeyen, anketi doldurmak istemeyen öğrenciler çalışmaya dâhil edilmeyip sadece eğitime katılmıştır. Araştırmada öğrencilerin okul numarası ile ön test ve son test eşleştirilmesi yapılmış̧ır. Araştırmada el yıkama becerilerinin gözlenmesi sırasında öğrencilerin kaygı yaşamasını önlemek için el yıkama gözlem formu el yıkama işlemi sonrasinda öğrencilere fark ettirilmeden doldurulmuştur.

$\mathrm{Bu}$ çalışmanın yazılmasında araştırma ve yayın etiğine, bilimsel ahlak kurallarına uyulmuş, başkalarının eserlerinden yararlanılması durumunda bilimsel normlara uygun olarak atıfta bulunulmuş, çalışmanın içerdiği yenilik ve sonuçlar başka bir yerden alınmamış ve kullanılan verilerde herhangi bir tahrifat yapılmamıştır.

\section{Bulgular}

Çalışmaya katılan öğrencilerin $\% 51.5$ 'i üçüncü sınıfta öğrenim görmektedir ve \%50.5'i kız öğrencidir. Öğrencilerin \%28.9'unun baba eğitim durumu lise iken \%28.4'ünün anne eğitim durumu ortaokuldur. Öğrencilerin \%36.1'i ellerini en son kahvaltıda yıkadığını, \% 26.3’ü ise en son sabah kalkınca ellerini yıkadığını belirtmiştir (Tablo 1)

Tablo 1. Öğrencilerin Sosyo-Demografik Özellikleri $(n=194)$

\begin{tabular}{|c|c|c|}
\hline Değişkenler & $\mathbf{n}$ & $\%$ \\
\hline \multicolumn{3}{|l|}{ Sinıf } \\
\hline $3 . \sin 1 f$ & 100 & 51.5 \\
\hline 4.sinif & 94 & 48.5 \\
\hline \multicolumn{3}{|l|}{ Cinsiyet } \\
\hline $\mathrm{K} 1 \mathrm{z}$ & 98 & 50.5 \\
\hline Erkek & 96 & 49.5 \\
\hline \multicolumn{3}{|c|}{ Babanın öğrenim durumu } \\
\hline Okuma yazma biliyor & 10 & 5.1 \\
\hline İlkokul mezunu & 44 & 22.7 \\
\hline Ortaokul mezunu & 45 & 23.2 \\
\hline Lise mezunu & 56 & 28.9 \\
\hline Üniversite mezunu & 49 & 20.1 \\
\hline \multicolumn{3}{|c|}{ Annenin öğrenim durumu } \\
\hline Okuma yazma biliyor & 17 & 8.8 \\
\hline İlkokul mezunu & 40 & 20.6 \\
\hline Ortaokul mezunu & 55 & 28.3 \\
\hline Lise mezunu & 51 & 26.3 \\
\hline Üniversite mezunu & 31 & 16.0 \\
\hline \multicolumn{3}{|c|}{ Ellerini en son ne zaman ylkadt } \\
\hline Akşam yatmadan önce & 18 & 9.3 \\
\hline Sabah kalkınca & 51 & 26.3 \\
\hline Kahvaltıda & 70 & 36.1 \\
\hline İki saat önce & 39 & 20.1 \\
\hline Bir saat önce & 16 & 8.2 \\
\hline
\end{tabular}


Tablo 2. Öğrencilerin Ĕ̆itim Öncesi ve Sonrast El Yıkama Stklığı (n=194)

\begin{tabular}{|c|c|c|c|c|c|c|c|c|c|c|}
\hline \multirow[t]{3}{*}{ El Yıkama Durumu } & \multicolumn{4}{|c|}{ Ĕgitim Öncesi } & \multicolumn{4}{|c|}{ Eğitim Sonrası } & \multirow{3}{*}{$\begin{array}{c}\text { Test } \\
\text { değeri } \\
\text { X }^{2}\end{array}$} & \multirow{3}{*}{$\underset{\text { değeri }}{p}$} \\
\hline & \multicolumn{2}{|c|}{ Evet } & \multicolumn{2}{|c|}{ Hayır } & \multicolumn{2}{|c|}{ Evet } & \multicolumn{2}{|c|}{ Hayır } & & \\
\hline & $\mathbf{n}$ & $\%$ & $\mathbf{n}$ & $\%$ & $\mathbf{n}$ & $\%$ & $\mathbf{n}$ & $\%$ & & \\
\hline Sabah uyanınca & 66 & 34.0 & 128 & 66.0 & 157 & 80.9 & 37 & 19.1 & 85.263 & .000 \\
\hline Yemekten önce & 95 & 49.0 & 99 & 51.0 & 163 & 84.0 & 31 & 16.0 & 62.347 & .000 \\
\hline Yemekten sonra & 69 & 35.6 & 125 & 64.4 & 156 & 80.4 & 38 & 19.6 & 85.011 & .000 \\
\hline Tuvaletten önce & 54 & 27.8 & 140 & 72.2 & 127 & 65.5 & 67 & 34.5 & 67.325 & .000 \\
\hline Tuvaletten sonra & 85 & 43.8 & 109 & 56.2 & 165 & 85.1 & 29 & 14.9 & 78.013 & .000 \\
\hline Dışarıdan gelince & 68 & 35.1 & 126 & 64.9 & 150 & 77.3 & 44 & 22.7 & 80.012 & .000 \\
\hline Oyundan sonra & 78 & 40.2 & 116 & 59.8 & 175 & 90.2 & 19 & 9.8 & 93.091 & .000 \\
\hline Eller kirlenince & 65 & 33.5 & 129 & 66.5 & 183 & 94.3 & 11 & 5.7 & 116.008 & .000 \\
\hline
\end{tabular}

İstatistiksel anlamlılık düzeyi: $p<.05, \mathrm{X}^{2}$ : McNemar test

Öğrencilerin eğitim öncesi ve sonrası el yıkama durumları karşılaştırıldığında el yıkama zamanlarını içeren tüm maddelerde eğitim öncesine göre istatistiksel olarak anlamlı bir fark olduğu saptandı $(p<.001)$. Eğitim öncesinde öğrencilerin \%34'ü sabah uyanınca, \%49'u yemekten önce, \%35.6's1 yemekten sonra, \%27.8'i tuvaletten önce, \%43.8'i tuvaletten sonra, \%35.1'i dışarıdan eve gelince, \%40.2'si oyun oynadıktan sonra, \%33.5'i eller kirlenince ellerini yıkadığını belirtmiştir. Eğitim sonrası ise; \%80.9'u sabah uyanınca, \%84'ü yemekten önce, \%80.4'ü yemekten sonra, \%65.5'i tuvaletten önce, \%85.1'i tuvaletten sonra, \%77.3'ü dışarıdan eve gelince, \%90.2'si oyun oynadıktan sonra, \%94.3'ü eller kirlenince ellerini yıkadığını ifade etmiştir (Tablo 2). El yıkama eğitimi sonrası el yıkama durumuna ilişkin olumlu davranış sergileme oranlarının arttığı görüldü.

Tablo 3. Öğrencilerin Ĕğitim Öncesi ve Sonrası El Hijyeni ile İlgili Önermelere Verdikleri Yanıtların Karşılaşstırılması

\begin{tabular}{|c|c|c|c|c|c|c|c|c|c|c|}
\hline \multirow[t]{3}{*}{ Önermeler } & \multicolumn{4}{|c|}{ Ĕ̆itim öncesi } & \multicolumn{4}{|c|}{ Ĕ̆itim sonrası } & \multirow{3}{*}{$\begin{array}{c}\text { Test } \\
\text { değeri } \\
X^{2}\end{array}$} & \multirow{3}{*}{$\underset{\text { değgeri }}{p}$} \\
\hline & \multicolumn{2}{|c|}{ Evet } & \multicolumn{2}{|c|}{ Hayır } & \multicolumn{2}{|c|}{ Evet } & \multicolumn{2}{|c|}{ Hayır } & & \\
\hline & $\mathbf{n}$ & $\%$ & $\mathbf{n}$ & $\%$ & $\mathbf{n}$ & $\%$ & $\mathbf{n}$ & $\%$ & & \\
\hline Elleri yıkamak için 10 saniye süre yeterli & 159 & 82.0 & 35 & 18.0 & 25 & 12.9 & 169 & 87.1 & 132.007 & .000 \\
\hline Eller ılık su ile yıkanmalı & 54 & 27.8 & 140 & 72.2 & 181 & 93.3 & 13 & 6.7 & 125.008 & .000 \\
\hline Eller yıkanmadan önce takılar çıkarılmalı & 83 & 42.8 & 111 & 57.2 & 173 & 89.2 & 21 & 10.8 & 88.011 & .000 \\
\hline Eller yıkandıktan sonra iyice kurulanmalı & 92 & 47.4 & 102 & 52.6 & 188 & 96.9 & 6 & 3.1 & 94.010 & .000 \\
\hline El temizliği için sadece su yeterli & 84 & 43.3 & 110 & 56.7 & 5 & 2.6 & 189 & 97.4 & 75.111 & .000 \\
\hline
\end{tabular}

İstatistiksel anlamlılık düzeyi: $p<.05, \mathrm{X}^{2}:$ McNemar test

Öğrencilerin eğitim öncesi ve sonrası el hijyeni bilgisi ile ilgili önermelere verdikleri yanıtlar karşılaştırıldığında, el yıkama eğitimi sonrası öğrencilerin el yıkamaya ilişkin bilgisinde eğitim öncesine göre istatistiksel olarak anlamlı fark saptandı $(p<.001)$. Eğitim öncesinde öğrencilerin \%82'si el yıkama için 10 saniye sürenin yeterli olduğunu düşünmekte iken eğitim sonrası el yıkama için 10 saniye sürenin yeterli olduğunu düşünen öğrencilerin oranı \%12.9 dur. Eğitim öncesinde ellerin 1lık suyla yıkanması gerektiğini düşünen öğrencilerin oranı \%27.8 iken eğitim sonrasında öğrencilerin \%93.3'ü ellerin 1l1k suyla yıkanması gerektiğini düşündüğünü belirtmiştir. Eğitim öncesi öğrencilerin \%42.8'i elleri yıkamadan önce varsa takıların çıkarılması gerektiğini düşünmekte iken eğitim sonrası bu oran\%89.2'dir. Öğrencilerin \%47.4'ü ellerin yıkandıktan sonra kurulanması gerektiğini düşünmekte iken eğitim sonrası \%96.9'u ellerin yıkandıktan sonra kurulanması gerektiğini belirtmişlerdir. Eğitim öncesi öğrencilerin \%43.3'ü el temizliği için sadece suyun yeterli olduğunu belirtmiş iken eğitim sonrası el temizliği için sadece suyun yeterli olduğunu düşünen öğrencilerin oranı \%2.6'dır (Tablo 3). 
Tablo 4.Öğrencilerin Ĕ̆itim Öncesi ve Sonrası El Yıkama Becerilerinin Karşılaştırılması

\begin{tabular}{|c|c|c|c|c|c|c|c|c|c|c|}
\hline \multirow[t]{3}{*}{ Basamaklar } & \multicolumn{4}{|c|}{ Ĕgitim öncesi } & \multicolumn{4}{|c|}{ Eğitim sonrası } & \multirow{3}{*}{$\begin{array}{c}\text { Test } \\
\text { Değeri } \\
\text { X }^{2}\end{array}$} & \multirow{3}{*}{$\underset{\text { değeri }}{p}$} \\
\hline & \multicolumn{2}{|c|}{ Uyguladı } & \multicolumn{2}{|c|}{ Uygulamadı } & \multicolumn{2}{|c|}{ Uyguladı } & \multicolumn{2}{|c|}{ Uygulamadı } & & \\
\hline & $\mathbf{n}$ & $\%$ & $\mathbf{n}$ & $\%$ & $\mathbf{n}$ & $\%$ & $\mathbf{n}$ & $\%$ & & \\
\hline Giysi kollarını yukarı çekme & 123 & 63.4 & 71 & 36.6 & 177 & 91.2 & 17 & 8.8 & 39.014 & .000 \\
\hline Elleri bir miktar su ile islatma & 86 & 44.3 & 108 & 55.7 & 148 & 76.3 & 46 & 23.7 & 50.284 & .000 \\
\hline Musluğu kapatma & 69 & 35.6 & 125 & 64.4 & 177 & 91.2 & 17 & 8.8 & 100.430 & .000 \\
\hline Eline bir miktar sabun alma & 101 & 52.1 & 93 & 47.9 & 188 & 96.9 & 6 & 3.1 & 85.011 & .000 \\
\hline Elleri bir miktar sabunla iyice köpürtme & 98 & 50.5 & 96 & 49.5 & 170 & 87.6 & 24 & 12.4 & 60.012 & .000 \\
\hline Parmak aralarını ovma & 93 & 47.9 & 101 & 52.1 & 169 & 87.1 & 25 & 12.9 & 55.147 & .000 \\
\hline Başparmakları elinin içine alarak ovma & 110 & 56.7 & 84 & 43.3 & 178 & 91.8 & 16 & 8.2 & 60.662 & .000 \\
\hline El sırtını ovma & 95 & 49.0 & 99 & 51.0 & 178 & 91.8 & 16 & 8.2 & 75.551 & .000 \\
\hline Bilekleri ovma & 88 & 45.4 & 106 & 54.6 & 167 & 86.1 & 27 & 13.9 & 66.857 & .000 \\
\hline Parmak uçlarını el içine alarak ovma & 102 & 52.6 & 92 & 47.4 & 185 & 95.4 & 9 & 4.6 & 79.106 & .000 \\
\hline Elleri iyice durulama & 86 & 44.3 & 108 & 55.7 & 189 & 97.4 & 5 & 2.6 & 99.086 & .000 \\
\hline Kâğıt havlu ile musluğu kapatma & 66 & 34.0 & 128 & 66.0 & 154 & 79.4 & 40 & 20.6 & 80.521 & .000 \\
\hline Elleri iyice kurulama & 89 & 45.9 & 105 & 54.1 & 181 & 93.3 & 13 & 6.7 & 82.810 & .000 \\
\hline Kâğıt havluyu çöpe atma & 83 & 42.8 & 111 & 57.2 & 179 & 92.3 & 15 & 77 & 94.010 & .000 \\
\hline
\end{tabular}

İstatistiksel anlamlılık düzeyi: $p<.05, \mathrm{X}^{2}:$ McNemar test

Öğrencilerin eğitim öncesi ve eğitim sonrası el yıkama becerileri karşılaştırıldığında, eğitim sonrasında tüm el yıkama basamaklarında eğitim öncesine göre istatistiksel olarak anlamlı bir fark saptandı $(p<.001)$. Eğitim öncesinde öğrencilerin \%63.4'ü giysi kollarını yukarı çekme davranışını gösterirken, eğitim sonrasında bu davranışın oranı \% 01.2 'dir. Eğitim öncesinde ellerini yıkamadan önce ellerini ıslatan öğrencilerin oranı \%44.3 iken eğitim sonrasında öğrencilerin \% 76.3 'ü ellerini yıkamadan önce ellerini ıslatma davranışı göstermiştir. Eğitim öncesinde el yıkama basamaklarını uygularken musluğu kapatan öğrencilerin oranı \%35.6 iken eğitim sonrasında öğrencilerin \%91.2’si el yıkama basamaklarını uygularken musluğu kapatmıştır. Eğitim öncesinde öğrencilerin \%52.1'i eline bir miktar sabun alırken, eğitim sonrasında bu oran \%96.9' dur. Eğitim öncesinde ellerini bir miktar sabunla iyice köpürten öğrencilerin oranı \%50.5 iken eğitim sonrasında öğrencilerin \%87.6's1 ellerini bir miktar sabunla iyice köpürtmüştür. Eğitim öncesinde elleri kenetleyerek parmak aralarını ovma davranışını gösteren öğrencilerin oranı \%47.9 iken eğitim sonrasında öğrencilerin \%87.1'i ellerini kenetleyerek parmak aralarını ovma davranış1 göstermiştir. Eğitim öncesinde öğrencilerin \%56.7'si başparmağını elinin içine alıp ovarken, eğitim sonrasında bu oran \%91.8'dir. Eğitim öncesinde öğrencilerin \%49.0`1 el sırtını ovarken, eğitim sonrasında bu oran \%91.8'dir. Eğitim öncesinde el bileklerini ovma davranışı gösteren öğrencilerin oranı \%45.4 iken eğitim sonrasında öğrencilerin \%86.1'i ellerini yıkarken bileklerini ovmuştur. Eğitim öncesinde öğrencilerin \%52.6's1 parmak uçlarının elinin içine alıp ovarken, eğitim sonrasında bu oran \%95.4'dür. Eğitim öncesinde ellerindeki sabunu bol su ile durulayan öğrencilerin oranı \%44.3 iken eğitim sonrasında öğrencilerin \%97.4’ü ellerindeki sabunu bol su ile durulamıştır. Eğitim öncesinde öğrencilerin \%34.0'1 musluğu kağıt havlu kullanarak veya musluğa su tutarak kapatırken, eğitim sonrasında bu oran \%79.4'dür. Eğitim öncesinde kağıt havlu ile parmak araları da dâhil ellerini iyice kurulama davranışı gösteren öğrencilerin oranı \% 45.9 iken eğitim sonrasında öğrencilerin \% 03.3 'ü kağıt havlu ile parmak araları da dâhil ellerini iyice kurulamıştır. Eğitim öncesinde öğrencilerin \%42.8'i kullandıkları kağıt havluyu çöpe atarken, eğitim sonrasında bu oran \%92.3'dür (Tablo 4). El yıkama eğitimi sonrası el yıkama beceri oranlarının arttığı görüldü.

\section{Tartışma}

Çalışmada eğitim öncesinde öğrencilerin ellerini uygun sıklıkta yıkamadığı, el yıkama durumları incelendiğinde her bir durum için öğrencilerin yarıdan fazlasının ellerini yıkamadığı belirlenmiştir. Çalışmada öğrencilerin eğitim öncesi el yıkama durumları daha önce yapılan çalışmalara $(1,3,7,8,14)$ göre oldukça düşüktür. Sosyoekonomik düzeyin el yıkama davranışlarının şekillenmesinde etkili bir faktör olduğu daha önce yapılan bir çalışmada belirtilmiştir (32). Bu çalışmada el yıkama sıklığının 
düşük bulunması çalışmanın yürütüldüğü okulun sosyoekonomik düzeyin düşük olduğu bir bölgede bulunması, bilinç/farkındalık durumunun daha düşük olmasından kaynaklandığı düşünülmektedir. Çalışmada öğrencilerin yarıdan fazlasının yemekten önce ve tuvaletten sonra ellerini yıkamadığı belirlenmiştir. Bu sonuç, enfeksiyon hastalıklarının yayılımını önlemede özellikle yemekten önce ve tuvaletten sonra el yıkamanın önemi okullarda enfeksiyon hastalıklarını önleme çalışmalarının ve el hijyeni eğitimlerinin ne kadar önemli olduğunun bir göstergesidir.

Öğrencilerin eğitim öncesinde en sık yemekten önce ellerini yıkadığı (\%49) bulunmakla birlikte bu oran daha önce yapılan çalışmalardaki $(1,3,7,14,17,28,33)$ sonuçlara göre daha düşüktür. Daha önce yapılan çalışmalarda eğitim öncesi öğrencilerin en sik tuvaletten sonra ellerini yıkadığı belirtilmiştir $(1,7,14,17,26)$. Bu çalışmada öğrencilerin \%72.2'sinin tuvaletten önce ellerini yıkamadığı görülmektedir. Benzer olarak Cevizci ve arkadaşlarının (2014) çalışmasında da öğrencilerin tuvaletten önce $(\% 33,3)$ el yıkama durumlarının düşük olduğu bulunmuştur (1). Ürdün'de okul çağı çocuklarda yapılan bir çalışmada tuvaletten önce daima el yıkadığını belirten öğrencilerin oranı \%6,1 iken tuvaletten önce asla ellerini yıkamadığını belirten öğrencilerin oranı ise \%32,7'dir (14). Aslan ve arkadaşlarının (2006) yapmış olduğu çalışmada da tuvaletten önce $(\% 35,7)$ el yıkama sıklığının düşük bulunduğu görülmektedir (7). Öncü ve arkadaşlarının (2018) ilkokul öğrencilerinde yaptığı çalışmada tuvaletten önce el yıkama sıklığı en düşük bulunmuştur (26). Kitiş ve Bilgili’nin (2011) çalışmasında ise öğrencilerin en sık elleri kirlendiğinde ellerini yıkadığı bulunmuştur (3). Literatüre paralel olarak bu çalışmada tuvaletten önce el yıkama sıklığının düşük bulunması öğrencilerin el hijyeni öneminin, enfeksiyon bulaş yolları bilgilerinin yetersiz olması ile açıklanabilir. Çocukların oyun çağı dönemde olmaları sebebiyle oyuna dalarak tuvalet ihtiyacını geciktirmesi ve tuvaletlerin temiz bir ortam olmadığı düşüncesiyle tuvalet öncesinde ellerini yıkamadığı düşünülmektedir.

Öğrencilerin eğitim sonrasındaki el hijyeni durumu/sıklığı eğitim öncesine göre artmış olup $\mathrm{H}_{1}$ hipotezi kabul edilmiştir (Tablo 2). Okul öncesi çocuklarda rol play yöntemi ile uygulanan el yıkama programı sonrasında programa katılan çocukların programa katılmayan çocuklara göre el yıkama sıklığının arttı̆̆ı belirtilmiştir (28). Shrestha ve Angolkar'ın (2015) çalışmasında öğrencilere verilen el hijyeni eğitiminin el yıkama sıklığının artmasında etkili olduğu görülmüştür (34). Eğitim sonrasında el yıkama sıklığında en fazla artış \%60.8 oranında eller kirlenince ve \%50.0 oranında oyun oynadıktan sonra durumlarında yaşanmıştır. En az artış yaşanan durum ise, \%35 oranında artış ile yemekten önce el yıkama durumudur. Her bir durum için eğitim sonrasında eğitim öncesine göre en az \%35 oranında bir artış sağlanması eğitimin etkinliğinin yüksek olduğunu göstermektedir. Kurum gözetiminde ve korumasında yaşayan çocuklarla yapılan bir müdahale çalışmasında eğitim sonrasında öğrencilerin el yıkama sıklığı en fazla "oyun oynadıktan sonra” durumunda artış göstermiştir (17). İlköğretim öğrencilerinde yapılan başka bir çalışmada ise eğitim sonrasında "tuvaletten önce" el yıkama sıklığı en çok artış yaşanan durumdur (3). Öğrencilere el hijyeni eğitimlerinin yanı sıra enfeksiyon bulaş yolları hakkında bilgi verilmesi el yıkama sıklığını artırabilir. Ayrıca yetişkin rol-model (öğretmen, anne-baba gibi) kullanılarak el yıkama eğitimleri verilmesi düzenli el yıkama alışkanlığını artırabilir. El hijyeni eğitimlerine okul öncesi dönemde başlanması ve bu eğitimlerin sonraki dönemlerde tekrarlanarak pekiştirilmesi el yıkama davranışının sürdürülmesini sağlayacağı düşünülmektedir. Nitekim okul öncesi dönemdeki çocuklarla yapılan randomize kontrollü deneysel bir çalışmada çocuklara uygulanan kitap, online oyun, müzik gibi aktiviteleri içeren çok bileşenli bir müdahalenin çocukların el yıkama bilgi ve becerilerinde artış sağladığı görülmektedir (35).

Öğrencilerin eğitim sonrasındaki el hijyeni bilgi düzeyleri eğitim öncesine göre artmış olup $\mathrm{H}_{2}$ hipotezi kabul edilmiştir (Tablo 3). Öğrencilerin elerin ne kadar süre ile yıkanması gerektiğine ilişkin bilgisi yetersiz bulunmuştur. Eğitim öncesinde "Elleri yıkamak için 10 saniye süre yeterlidir" önermesine verilen doğru yanıt oran $\% 18$ iken bu oran eğitim sonrasında \%87.1'e yükselmiştir. Kitiş ve Bilgili'nin (2011) çalışmasında aynı önermeye doğru yanıt veren öğrencilerin oranı eğitim öncesinde \%66.2 iken eğitim sonrasında \%76.7'ye çıkmıştır (3). Eğitim öncesinde \%27.8 olan “Eller ılık suyla yıkanmalı" önermesine verilen doğru yanıt oranı eğitim sonrasında \%93.3'e çıkmıştır. Kitiş ve Bilgili’nin (2011) çalışmasında bu önermeyi doğru yanıtlayan öğrencilerin oranı eğitim öncesinde \%75, eğitim sonrasında ise \%79.3 olarak bulunmuştur (3). Aslan ve arkadaşlarının (2006) çalışmasında suyun sıcaklığının ılık olması gerektiğini belirten öğrencilerin oranı ise \%71.4 olarak saptanmıştır (7). Çalışmada elleri yıkamadan önce takıların çıkarılması gerektiği ifadesine doğru yanıt veren öğrencilerin oranı eğitim öncesi \%42.8 iken eğitim sonrası bu oran \%89.2 ye çıkmıştır. Kitiş ve Bilgili’nin (2011) çalışmasında el yıkama öncesi takıların çıkarılması gerektiği önermesini doğru yanıtlayan öğrencilerin oranı eğitim öncesinde \% $\%$, eğitim sonrasında ise \%90.1 olarak bulunmuştur (3). Aslan ve arkadaşlarının (2006) çalışmasında takıların çıkarılması gerektiğini belirten öğrencilerin oranı \%77.4'tür (7). Ellerin yıkandıktan sonra kurulanması gerektiği önermesine eğitim öncesinde öğrencilerin \%47.4'ü doğru yanıt vermiş iken bu ifadeye doğru yanıt verme oranı eğitim sonrasında \%96.9 olmuştur. Aynı ifade Kitiş ve Bilgili’nin (2011) çalışmasında \%98 iken eğitim sonrasında \%99.3'e çıkmıştır (3). Aslan ve arkadaşlarının (2006) çalışmasında ellerin kurulanması gerektiğini belirten öğrencilerin oranı \%96.4'tür (7). "El temizliği için sadece su yeterli” önermesine verilen doğru yanıt oranı \%56.7 iken bu oran eğitim sonrasında \%97.4'e yükselmiştir. Kitiş ve Bilgili'nin (2011) çalışmasında ise, aynı önermeye doğru yanıt veren öğrencilerin oranı eğitim öncesinde \%80.9, eğitim sonrasında ise \%86.4 dır (3). Aslan ve arkadaşlarının (2006) çalışmasında elleri yıkamak için sadece suyun yeterli olduğunu belirten öğrencilerin oranı \%4.8 dir (7). Öğrencilerin bilgi önermelerine yanıtları değerlendirildiğinde, eğitim öncesinde ifadelere doğru yanıt verme oranları Kitiş ve Bilgili’nin (2011) çalışmasına ve Aslan ve arkadaşlarının (2006) çalışmasına göre daha düşüktür (3,7). Bu farklılığın Aslan ve arkadaşlarının (2006) çalışması ile Kitiş ve Bilgili'nin (2011) çalışmasının örnekleminin yaşadığı yerin büyükşehir olmasına bağlı öğrencilerin konuya farkındalığının daha yüksek olduğu düşünülebilir $(3,7)$. Çalışmada öğrencilerin eğitim öncesi ve sonrası bilgi ifadelerine verdiği yanıtlar değerlendirildiğinde öğrencilerin bilgilerinin eğitim sonrasında arttığı görülmektedir. Shrestha ve Angolkar'1n (2015) çalışmasında öğrencilere verilen el hijyeni eğitiminin, öğrencilerin el yıkama bilgi düzeylerinin artmasında etkili olduğu görülmüştür (34). Literatürdeki çalışmalara $(1,3,9,15,17,36)$ göre eğitim sonrasında daha fazla artış sağlandığından rol-play yöntemi ile verilen el hijyeni eğitiminin diğer yöntemlere göre etkinliğinin daha yüksek olduğu söylenebilir.

Öğrencilerin eğitim sonrasındaki el yıkama becerileri eğitim öncesine göre artmıştır ve $\mathrm{H}_{3}$ hipotezi kabul edilmiştir $(p<.001)$ (Tablo 4). Çalışmada eğitim öncesinde el yıkama basamaklarından en çok uygulanan basamaklar sırasıyla giysi kollarını yukarı çekme (\%63.4), başparmakları elinin içine alarak ovma (\%56.7) dır. Eğitim öncesi öğrencilerin en az uyguladığı basamak ise kağıt havlu ile musluğu kapatma (\%34) adımıdır (Tablo 4). Eğitim öncesi el yıkama basamaklarını uygulamada 
literatürde farklı sonuçlar mevcuttur. Aslan ve arkadaşlarının (2006) çalışmasında "musluğu kapatarak elde kalan köpükle elleri ovma" ve "elleri yıkadıktan sonra musluğu su tutarak kapatma", Şahin ve arkadaşlarının (2008) çalışmasında "el bileklerini ovarak temizleme" ve "giysi kollarını sıvama", Kitiş ve Bilgili’nin (2011) çalışmasında "el bileklerini ovma” ve "elleri yıkarken musluğu kapatma", Cevizci ve arkadaşlarının (2015) çalışmasında "musluğu kağıt havlu ile kapatma" ve "her iki başparmağı diğer el ile ovma" en az uygulanan basamaklardır $(1,3,7,17)$.

Eğitim sonrasında uygulama sıklığında en fazla artış yaşanan el yıkama basamağı eğitim öncesine göre \%55.6'lık bir artış ile "elleri yıkarken musluğu kapatma" ve \%53.1'lik bir artış ile "elleri durulama” basamağıdır (Tablo 4). Benzer şekilde Kaya ve Aslan'ın (2009) çalışmasında da eğitim sonrasında en fazla artış "musluğu kapatarak elde kalan köpükle elleri ovma” basamağındadır (36). Kitiş ve Bilgili'nin (2011) çalışmasında ise eğitim sonrasında en fazla artış "el bileklerini ovma" basamağında olmuştur (3). Eğitim sonrasında en az artı̧ yaşanan uygulama basamağı \%27.8'lik bir artış ile "giysi kollarını yukarı çekme" ve \%32'lik bir artış ile “elleri bir miktar su ile ıslatma” basamağıdır (Tablo 4). Kaya ve Aslan'ın çalışmasında da eğitim sonrasında en az artışın "elleri bir miktar su ile 1slatarak sabunun köpürmesini sağlama” basamağı olduğu görülmüştür (36). Öğrencilerin el yıkama becerilerini eğitim sonrasında önemli derecede daha fazla uyguladıkları, doğru el yıkama basamaklarından her bir basamağın uygulanma sıklığının eğitim sonrasında arttığı görülmektedir. El yıkama becerilerinin geliştirilmesinde Rol oynama yöntemi ile uygulanan eğitimin etkili olduğu söylenebilir.

Rol Oynama (Rol-Play) yöntemi kullanılarak yapılan el hijyeni eğitiminin çocukların bilgi ve becerilerini olumlu yönde artırması hedeflenmiş olup $\mathrm{H}_{2}$ ve $\mathrm{H}_{3}$ hipotezi kabul edilmiştir. El yıkama eğitimlerinde bilgi artışı hedeflenirken aynı zamanda beceri artışı da hedeflenmekte bilgi ve becerilerin davranışa dönüşmesi için beceri eğitimlerinde ödül, oyun, gösteri gibi interaktif ve uygulamalı öğretim yöntemleri gibi çeşitli yöntemlerin kullanılması önerilmektedir $(1,7,17,25)$. Slayt, video, oyun gibi farklı yöntemlerle ve görsel araçlarla yapılan el yıkama eğitimi çalışmalarında öğrencilerin el yıkama bilgi ve becerilerinde artış sağlanmıştır $(1,3,4,15,17,27,28,35)$. Okul öncesi çocuklarda rol play yöntemi ile uygulanan el yıkama programı sonrasında programa katılan çocukların doğru el yıkama becerilerinde artış görülmüştür (28). Görsel ve işitsel eğitim araçları kullanılarak yapılan iki çalışmada çocuklara verilen el hijyeni eğitimi sonrasında el hijyeni bilgi ve becerilerinin arttığı belirtilmiştir (1,3). Aslan ve arkadaşlarının (2006) demonstrasyon ve video filmi izletme yöntemiyle yaptığı tek gruplu müdahale çalışmasında eğitim sonrasında öğrencilerin el yıkama becerilerinde artış saptanmıştır (7). Kurum gözetimi ve koruma altındaki çocuklara video sunumu ve demonstrasyon yöntemi ile el yıkama eğitiminin verildiği bir çalışmada öğrencilerin bilgi ve beceri uygulamalarında artış sağlanmıştır (17). İlköğretim öğrencilerinde yapılan başka bir çalışmada öğrencilere verilen eğitim sonrasında el yıkama bilgi ve becerilerinin arttı̆̆ı belirtilmiştir (8). İlköğretim öğrencilerine yönelik akran eğitimi ile uygulanan el yıkama müdahale çalışmalarında öğrencilerin el yıkama eğitimi sonrası el hijyeni bilgi ve becerilerinin arttı̆̆ görülmüştür ( 9 , 25,37). Öncü ve arkadaşlarının (2018) interaktif eğitim ve demonstrasyon kullanarak yaptığı randomize kontrollü bir araştırmada interaktif eğitim alan öğrencilerin el yıkama etkinliği kontrol gruplarına göre daha fazla artış gösterdiği belirtilmiştir (26). Uygun pedagojik ve interaktif eğitim yöntemlerinin eğitimin etkinliğini büyük oranda artırdığı bu çalışmada ve konu ile ilgili yapılmış olan diğer çalışmalarda da kanıtlanmıştır $(1,3,7,9,17,25,26,35-37)$.

Bilgi ve becerilerdeki değişimin davranışa dönüşebilmesi için zamana ihtiyaç vardır. Bu çalışmada eğitim verildikten 1 ay sonra tek bir izlem yapılması bu çalışmanın bir kısıtlılığıdır. Eğitim sonrasında bilgi ve becerilerde artış gözlenmiştir ancak el yıkama eğitiminin davranışa dönüşüp dönüşmediğini gözlemek amacıyla tekrarlı izlemler içeren çalışmalar yapılması önerilir. Ailelerin ve öğretmenlerin doğru el yıkama bilgi ve becerilerinin geliştirilmesinde uygun öğretim yöntem ve araçlarının kullanımı ile çocukların bilgi ve cesaret aldıkları grupların el yıkama konusunda aktive edilmesi sağlanabilir $(2,14,15)$. Ayrıca el yıkama davranışlarının geliştirilmesi ile ilgili eğitim müdahalesi çalışmalarında ebeveyn ve öğretmenlerin de çalışma gruplarına ve çalışmaya dâhil edilmesi önerilir. Öğrencilerin sadece bilgi edinmesinin yeterli olmadığ 1 aynı zamanda olumlu davranış geliştirmesi gerektiği hijyen eğitimlerinin sağlık profesyonelleri tarafindan uygulanması, bu eğitimlerin belirli aralıklarla düzenli olarak tekrarlanması önerilir. Türkiye'de okul hemşirelerinde yapılan bir çalışmaya göre; okul hemşirelerinin sağlık eğitimi ve danışmanlık işlevlerini yeterli düzeyde yerine getirmedikleri belirlenmiştir (24). Türkiye'de okul sağlı̆̆ın hizmetlerinin yürütülmesinden sorumlu olan birimlerde çalışan hemşireler okulda sağlığı koruma ve geliştirmeye yönelik sağlık eğitimlerinin koordine edilmesinde düzenli olarak uygulanmasında aktif görev almalıdır (38). Okul hemşirelerinin en çok uygulaması gereken rollerinden biri olan eğitim ve danışmanlık rolüne ilişkin hemşireleri geliştirici ve teşvik edici program ve politikalar geliştirilmelidir.

Öğrencilerin el yıkama davranışlarının önündeki engelleri kaldırmada tuvalet ve lavaboların teknik imkanlarının geliştirilmesi ve el hijyeni için gereken malzeme eksikliklerinin tamamlanması önemli olacağı düşünülmektedir. Okul sağlığı hemşirelerinin okul lavabolarını gereken malzemelerin temini ve temizlik açısından denetlemesi, eksiklikleri okul idaresine bildirmesi, okul idaresinin de öğrencilerin hijyen bilgi, beceri ve uygulamalarını artıracak programlar oluşturması ve uygulaması okulda el yıkama konusunda farkındalık oluşmasına, öğrencilerin el yıkama bilgi ve becerilerinin gelişmesine katkı sağlayacaktır.

\section{Kisitlılıklar}

Araştırmanın Karaman il merkezindeki bir ilkokulda öğrenim gören 3. ve 4. sınıf öğrencileri ile yapılması ve kontrol grubunun olmaması araştırmanın bir sınırlılığıdır.

\section{Sonuçların Uygulamada Kullanımı}

Doğru el yıkama, enfeksiyon hastalıklarının önlenmesinde en önemli uygulamalardandır. Doğru el yıkama bilgi ve becerilerinin çocukluk döneminde kazanılması davranışın yaşam boyu sürdürülmesinde etkilidir. Çocukların el yıkama bilgi beceri ve uygulamalarının geliştirilmesi amacıyla okullarda sağlı̆̆ı geliştirme programları oluşturulmalı ve farklı yöntemlerle 
uygulanmalıdır. Rol Oynama (Rol-Play) yöntemi, çocukların el hijyeni bilgi beceri ve uygulamalarının öğretilmesinde etkili bir yöntemdir. Rol-oynama, çocukların eğlenerek öğrenmesinin yanında eğitime katılımını da sağlayan destekleyici bir eğitim yöntemi olarak okul sağlığı hemşireleri ve öğretmenler tarafından kullanılabilir. El yıkama eğitimlerinin okul öncesi dönemden başlatılması, belirli aralıklarla eğitim ve gözlemler ile sürdürülmesi bilgi ve becerilerin kalıcı davranışa dönüşmesini sağlayacaktır. Çocuklara verilen eğitimlerde yaş grubuna uygun araç-gereç ve yöntemlerin (video, rol-play, power-point sunusu, vb.) kullanılması önerilmektedir. Okulda lavabo/tuvaletlerin temizliği ve gerekli malzemelerin hazır bulundurulması, çocukların öğretilen bilgi ve becerileri uygulamasına etki edeceğinden bu konuda okul idaresi ve öğretmenlerle işbirliği yapılmalıdır.

\section{Bilgilendirme}

Çalışmada yer alan yazarlar makalenin hazırlanmasında ve düzeltilmesinde eşit katkıda bulunmuştur. Yazarların çalışmaya katkıları; fikir/kavram ŞK; tasarım ŞK, HY; denetleme/danışmanlık ŞK; veri toplama ve işleme HY; analiz ve yorum ŞK, HY; kaynak taraması ŞK, HY; makale yazımı ŞK, HY; eleştirel düşünme ŞK, HY. Yazarlar çalışmaya katılan tüm çocuklara, izin veren ebeveynlerine, okul yöneticilerine ve çalışmanın senaryosunda gönüllü olarak görev alan hemşirelik son sınıf öğrencilerine de teşekkür etmektedir. Yazarlar arasında herhangi bir çıkar çatışması yoktur. Araştırma herhangi bir proje kapsamında desteklenmemiştir ve araştırmada herhangi bir maddi destek/yardım alınmamıştır. Araştırmanın giderleri araştırmacılar tarafindan karşılanmıştır.

Araştırmanın uygulanması için bir üniversitenin Sağlık Bilimleri Fakültesine bağlı etik kurulundan etik izin (27.03.2019/18), çalışmanın yapıldığ ilin Valiliğinden ve İl Milli Eğitim Müdürlüğü’nden kurum izni (13.05.2019/9937154044-E.9374641) alınmıştır. 
Kaynaklar
1. Cevizci S, Uludağ A, Topaloğlu N, Babaoğlu U, Çelik M ve Bakar C. Developing students hand hygiene behaviors in a primary school from Turkey: a school-based health education study. Int J Med Sci Public Health 2014; 4(2): $155-161$.

2. Abay ŞE, Özvarış ŞB. İlkokul öğrencilerinin genel hijyen konusundaki ihtiyaçlarının saptanması. STED 2018; 27(5): 352357.

3. Kitiş Y, Bilgili N. İlköğretim öğrencilerinde el hijyeni ve el hijyeni eğitiminin etkinliğinin değerlendirilmesi. Maltepe Üniversitesi Hemşirelik Bilim ve Sanatı Dergisi 2011; 4(1): 93-102.

4. Türkiye İstatistik Kurumu. Türkiye Sağlı Araştırması 2014. TÜİK 2015. URL: https://data.tuik.gov.tr/tr/displaybulletin/?bulletin=turkiye-saglik-arastirmasi-2014-18854. 13 Ekim 2020

5. Türkiye İstatistik Kurumu. Türkiye Sağlı Araştırması $2016 . \quad$ TÜİK $2017 . \quad$ URL: https://data.tuik.gov.tr/Bulten/Index?p=Turkiye-Saglik-Arastirmasi-2016-24573 12 Mart 2021

6. Türkiye İstatistik Kurumu. Türkiye Sağlı Araştırması $2019 . \quad$ TÜİK $2020 . \quad$ URL: https://data.tuik.gov.tr/Bulten/Index?p=Turkiye-Saglik-Arastirmasi-2019-33661 12 Mart 2021

7. Aslan D, Mermerkaya MU, Kaya FE, Kaya H, Esen E, Koban Y ve ark. Ankara'da bir ilköğretim okulunda el yıkama konusunda yapılmış olan bir müdahale çalışması. Türkiye Klinikleri J Med Sci 2006; 26: 157-162.

8. Ayhan E, Gökler ME, Işıklı B, Önsüz F, Özay Ö, Aydın E ve ark. Eskişehir kırsalı ilköğretim öğrencilerinde el hijyeni bilgi ve uygulaması: müdahale çalışması. STED 2015; 24(3): 99-108.

9. Falus A, Lehotsky A, Gezsi A, Lukacs JA, Gradvohl E and Feith HJ. Pedagogical experiences in educating hand-washing among children a hygiene contribution to proper behavior during a pandemic. Open Access Journal of Microbiology and Biotecnology 2020; 5(5): 000180.

10. Akçay D. Okul ortamında bulaşıcı hastalıklardan korunmada okul hemşiresinin rolü. Cumhuriyet Hemşirelik Dergisi 2016; 5(2): 84-94.

11. Chittleborough CR, Nicholson AL, Basker E, Bell S ve Campbell R. Factors influencing hand washing behaviour in primary schools: process evaluation within a randomized controlled trial. Health Education Research 2012; 27(6): $1055-1068$.

12. Yılmaz A ve Yılmaz EG. İlköğretim okullarındaki temizlik ve hijyenin öğrenci görüşlerine göre değerlendirilmesi. Çukurova Üniversitesi Eğitim Fakültesi Dergisi 2014; 43(1): 74-89.

13. Mbakaya BC, Lee PH ve Lee RL. Hand hygiene intervention strategies to reduce diarrhoea and respiratory infections among school children in developing countries: a systematic review. Int J Environ Res Public Health 2017; 14(4): 371.

14. AlBashtawy M. Assessment of hand-washing habits among school students aged 6-18 years in Jordan. British Journal of School Nursing 2017; 12(1): 30-36.

15. Çövener Özçelik Ç, Aktaş E, Sefer H ve Ocakçı AF. Impact of toilet hygiene training program on school age children. HEMAR-G 2017; 19(2): 25-40.

16. T.C. Sağlık Bakanlığı. Türkiye el yıkama araştırması. Sağlığın Geliştirilmesi Genel Müdürlüğü 2012. URL: https://sbu.saglik.gov.tr/ekutuphane/yayin/450. 20 Mart 2019

17. Şahin MM, Vural S, Vurallı D, Yüksel S, Yıldız F ve Aslan D. 6-14 yaş grubu çocuklarda el yıkama ile ilgili bir müdahale çalışması. TSK Koruyucu Hekimlik Bülteni 2008; 7(1): 65-70.

18. Celik LA ve Pancoe DL. Healthy school environment: effectiveness of hand washing instruction in an elementary school setting. NASN School Nurse 2012; 27(4): 194-196.

19. Şahinöz T, Şahinöz S ve Kıvanç A. Sağlığı geliştirmenin en kolay yolu: okul sağlığı. Gümüşhane Üniversitesi Sağlık Bilimleri Dergisi 2017; 6(4): 303-312.

20. Ulutaşdemir N, Balsak H, Öztürk Çapur E ve Demiroğlu N. Halk sağlığı hemşireliğinin bir dalı: okul sağlığı hemşireliği. Türkiye Klinikleri J Public Health Nurs-Special Topics 2016; 2(1): 121-124.

21. Proctor ST, Lordi SL ve Zaiger DS. School Nursing Practice: Roles and Standards. Scarborough, ME: National Association of School Nurses; 1993.

22. American Nurses Association \& National Association of School Nurses. 3rd ed. School nursing: Scope and standards of practice. MD: Author; 2017.

23. T.C. Sağlık Bakanlığı. Hemşirelik yönetmeliğinde değişiklik yapılmasına dair yönetmelik. Resmi Gazete 2011. URL: http://www.resmigazete.gov.tr/eskiler/2011/04/20110419-5.htm. 20 Mart 2019

24. Altuntaş S ve Baykal Ü. Okul hemşirelerinin iş, iş ortamı, rol ve sorumluluklarına yönelik görüşleri. HEAD 2012; 9(1): 4350 .

25. Lehotsky A, Falus A, Lukacs A, Füzi A.R, Gradvohl E, Meszarosne Darvay S et al. Direct effect of contemporary health education programmes on the knowledge about hand hygiene and technique of hand washing in primary school age children. Orvosi Hetilap 2018; 159(12): 485-490.

26. Öncü E, Köksoy Vayısoğlu S, Lafci D, Yurtsever D, Bulut ER ve Peker E. Comparison of interactıve education versus fluorescent concretization on hand hygiene compliance among primary school students: a randomized controlled trial. The Journal of School Nursing. 2018; 20(10): 1-11.

27. Vizeshfar F, Zare M, Keshtkaran Z. Role-play versus lecture methods in community health volunteers. Nurse Education Today. 2019; 79: 175-179.

28. Lim HS, and Kwon IS. Development and effects of a hand-washing program using role-playing for preschool children. Child Health Nursing Research. 2019; 25(2): 123-132.

29. Samalot-Rivera A. Role playing in physical education to teach in the affective domain. Journal of Physical Education, Recreation \& Dance. 2014; 85(2): 41-43. 
30. Valizadeh L, Akbarzadeh, B, Ghiyasvandiyan S, Kuchakinejad Z, Zamanzadeh V, Aghajari P, et al. The effects of role play simulation and demonstration on pediatric peripheral venous catheter insertion skill among nursing students: a three group experimental study. Nursing and Midwifery Studies. 2021; 10(1): 1-6.

31. Cansever Z, Avsar Z, and Tastan K. Third year medical school students' experiences of revealing patients' stories through role playing. The Eurasian Journal of Medicine 2015; 47(1): 26.

32. Hao M, He, J, Zeng Y, Han W, Sa1 A, and Yamauchı T. A comprehensive assessment of hand washing: knowledge, attitudes and practices (KAP) and hand-washing behaviors among primary school students in northeast China. Sanitation Value Chain. 2021; 00026.

33. Mermer G, Durusoy R, Türk M ve Coyle SB. Hijyen eğitiminin öğrencilerin bilgi düzeyine ve okul devamsızlı̆̆ına etkisi. DEUHFED. 2016; 9(1): 16-22.

34. Shrestha A, ve Angolkar M. Improving hand washing among school children: an educational intervention in South India. Al Ameen J Med Sci. 2015; 8: 81-5.

35. Younie S, Mitchell C, Bisson MJ, Crosby S, Kukona A, and Laird K. Improving young children's handwashing behaviour and understanding of germs: The impact of A Germ's Journey educational resources in schools and public spaces. Plos One, 2020; 15(11): e0242134.

36. Kaya M, Aslan D. Ankara'da bir ilköğretim okulunda el yıkama konusunda bir müdahele çalışması. Erciyes Medical Journal/Erciyes Tıp Dergisi 2009; 31(2).

37. Molnár ZS, Varga L, Gyenes G, Lehotsky Á, Gradvohl E, Lukács Á.J, et al. Effectiveness of a Hungarian peer education handwashing programme in primary and secondary schools. Developments in Health Sciences. 2020. http://dx.doi.org/10.1556/2066.2020.00011

38. T.C. Sağlık Bakanlığı. Okulda sağlığın korunması ve geliştirilmesi programı. Halk Sağlığı Genel Müdürlüğü 2017. URL: https://hsgm.saglik.gov.tr/tr/cocukergen-sgp1/sagl\%C4\%B1g\%C4\%B1n-gelisitirlmesi/okuldasa\%C4\%9Fl\%C4\%B1\%C4\%9F\%C4\%B1n-korunmas\%C4\%B1-ve-geli\%C5\%9Ftirilmesi-program\%C4\%B1.html. Mayis 2020 